\title{
KEBIJAKAN POLITIK DALAM PENGEMBANGAN TRADISI AKADEMIK INTELEKTUAL PERGURUAN TINGGI KEAGAMAAN ISLAM
}

\author{
Wildani Hefni \\ Institut Agama Islam Negeri Jember \\ Jl. Mataram No. 1 Mangli Jember, 68136, Jawa Timur \\ Email: wildani91@gmail.com
}

\begin{tabular}{c|c|c}
\hline Received: & Revised: & Approved: \\
25/07/2018 & $05 / 08 / 2018$ & $18 / 08 / 2018$ \\
\hline
\end{tabular}

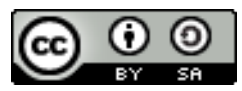

Kebijakan Politik Dalam Pengembangan Tradisi Akademik Intelektual Perguruan Tinggi Keagamaan Islam licensed under a Creative Commons Attribution-ShareAlike 4.0 International License

\begin{abstract}
Since the pilot project held by the Ministry of Religious Affairs of Indonesia as, the state has stepped up these efforts and, in the process, sought to increase the state's juricdiction over Islamic education in Indonesia. The ministry sought to turn Islamic higher education as a locomotive to develop the educational quality by sending Indonesian scholars into western countries. This study examines the political perspectives, not only within the framework of education as social fact, but also offers the analitical frameworks to explain how political state engages initiatives to enhance intellectuall Islamic higher education by linking social capital and intellectual capital.
\end{abstract}

Keyword: Muslim Intellectual, Policital Contestation, and State. 


\begin{abstract}
Abstrak
Sejak dimulainya program pembibitan calon dosen oleh Kementerian Agama Indonesia sebagai proyek percontohan, pemerintah mulai memasuki wilayah politik kebijakan dalam penguatan pengembangan tradisi akademik dalam konteks pendidikan Islam di Indonesia. Pemerintah berusaha untuk mengubah perguruan tinggi keagamaan Islam menjadi lokomotif pengembangan para intelektual dengan strategi pengiriman ke negara-negara Barat. Kajian ini ingin melihat kebijakan tersebut dari perspektif politik, tidak hanya sekedar permasalahan pendidikan sebagai fakta sosial, namun dalam kontekspolitik, kebijakan pemerintah terlibat dalam inisiasi peningkatan intelektual perguruan tinggi keagamaan dengan menghubungkan modal sosial dan modal intelektual.
\end{abstract}

Kata kunci: Intelektual Muslim, Kebijakan Politik, dan Negara.

\title{
A. Pendahuluan
}

Upaya peningkatan mutu pendidikan di perguruan tinggi keagamaan Islam menjadi tuntutan yang tidak terelakkan. Berbagai program dipersiapkan dalam rangka peningkatan mutu dosen agar mampu berdaya saing internasional melalui jejaring perguruan tinggi di luar negeri, baik dalam bidang pendidikan dan pengajaran, penelitian, publikasi, maupun pengabdian kepada masyarakat. Hal ini menjadi mega proyek yang senantiasasa direalisasikan untuk menciptakan minat pengetahuan (knowledge interest) ${ }^{1}$ di lingkungan perguruan tinggi keagamaan Islam. Upaya-upaya strategis melalui intervensi kebijakan yang mampu menghantarkan para dosen untuk mengaktualisasikan semua potensi akademiknya menjadi keniscayaan.

Berbagai program itu lahir dari sejarah panjang perguruan tinggi keagamaan Islam yang pada awalnya berdiri dengan beragam keterbatasan. Seiring berjalannya waktu, sudah banyak kebijakan yang dikeluarkan oleh pemerintah dalam konteks meningkatkan mutu dan relevansi perguruan tinggi keagamaan Islam. Kebijakan

${ }^{1}$ Minat pengetahuan didefinisikan sebagai jenis pengetahuan yang terbentuk secara berantai. Lihat R. Eyerman dan A. Jamison, Social Movement: A Cognitive Approach (Pensylvania: The Pensylvania State University Press, 1991), 129-30 Sebagai perbandingan, Burke memandang bahwa ide-ide dapat tersituasikan (situated) secara sosial dan dibentuk oleh pandangan dunia (world views) atau gaya-gaya pemikiran (styles of thought). Lihat P. Burke, A Social History of Knowledge: From Gutenberg to Diderot (Cambridge: Cambridge University Press, 2000), 70. 
itu terkonfirmasi dari Berbagai affirmativ action Kementerian Agama Republik Indonesia. Dalam konteks itu, tulisan ini akan mengkaji kebijakan politik negara yang dalam hal ini Kementerian Agama dalam pengembangan tradisi akademik di perguruan tinggi keagaman Islam.

Kebijakan politik kekuasaan mengalokasikan nilai-nilai secara keseluruhan. Hal ini mengandung konotasi tentang kewenangan pemerintah yang meliputi keseluruhan kehidupan bermasyarakat. David Easton menjelaskan bahwa pengambilan keputusan, kewenangan dan kebijakan adalah hal yang esensial dalam kehidupan politik. ${ }^{2}$ Easton mendefinisikan politik sebagai proses alokasi nilai dalam masyarakat secara otoritatif. Penggunaan kata secara otoritatif membuat konsep sistem politik Easton terhubung dengan negara.

Signifikansi tulisan ini terletak pada konseptualisasi kebijakan politik yang diberikan oleh negara berdampak cukup signifikan dalam pengembangan tradisi akademik di perguruan tinggi keagamaan Islam. Kebijakan politik sebagaimana dimaksud menjadi investasi dalam transformasi arah kajian akademik yang berdiri di luar diskursus setting sosial-politik, primordialisme organisasi ${ }^{3}$ dan otoritarianisme kuasa. ${ }^{4}$

\section{B. Konteks Politis Lahirnya Perguruan Tinggi Keagamaan Islam}

Lahirnya perguruan tinggi keagamaan Islam di Indonesia tidak bisa dilepaskan dari aspek politik. Pergulatan kepentingan politik menjadi salah satu unsur berdirinya perguruan tinggi keagamaaan Islam. Sensitivitas sosial muncul saat lembaga pendidikan tinggi milik pemerintah Belanda berdiri dan kemudian menjadi pilihan masyarakat pribumi. Lembaga pendidikan tinggi milik Belanda yaitu Sekolah Tinggi Teknik (Technische Hoogeschool) yang kini menjadi Institut Teknologi Bandung (ITB) berdiri tahun 1920 di Bandung,

${ }^{2}$ David Easton, Understanding Public Policy, dalam AG. Subarsono, Analisis Kebijakan Publik, Konsep, Teori dan Aplikasi (Yogyakarta: Pustaka Pelajar, 2000), 52.

${ }^{3}$ Farid Abdul Khalik, Al-Figh al-Siyasy al-Islamy: Mabadi' Dusturiyah al-Syura al-'Adl al-Musawa (Beirut: Dar al-Fikr, 1991), 162.

${ }^{4}$ Frederick M Denny, "Component of Religion: The Case of Islam," Oxford Journals: OAH Magazine of History 6, no. 3 (1992): 23-24. 
Sekolah Tinggi Hukum (Rechts Hoogeschool) didirikan pada tahun 1924 di Jakarta, dan Sekolah Tinggi Kedokteran (Geneeskundige Hoogeschool) berdiri pada tahun 1927 di Jakarta. ${ }^{5}$ Sekolah tinggi tersebut hanya diperuntukkan bagi para elit priyayi yang menyebabkan masyarakat umum sangat sulit, terlebih saat itu masyarakat dominan berada di kelas bawah.

Lembaga-lembaga sebagaimana disebut di atas merupakan produk pemerintah kolonial Belanda yang didirikan dalam rangka politik etis. Faktanya, mahasiswa pribumi yang terdaftar selama dua puluh satu tahun (1920-1941) hanya berjumlah 1.409 dari 3.242 mahasiswa. Ironisnya, mahasiswa pribumi terbatas pada anak-anak elit priyayi. Oleh karena itu, umat Islam mulai berkeinginan untuk mendirikan Perguruan Tinggi Islamsebagai wadah dan tempat menyemai pendidikan utamanya dari kalangan keluarga kurang mampu. Tidak hanya sebatas itu, keinginan untuk mendirikan perguruan tinggi keagamaan didorong oleh penegasan kecintaan terhadap konstruk pendidikan yang mengedepankan kearifan lokal pribumi, yang kemudian menjadi pembeda dan kultur dan identitas pendidikan dari kolonial Belanda yang mengenyampingkannilai-nilai pendidikan agama. ${ }^{6}$

Setting sosial politik saat itu kemudian menjadi penanda kuatnya desakan untuk mendirikan perguruan tinggi keagaamaan Islam sebagai manifestasi ide dan gagasan yang diperlukan untuk pendidikan keagamaan masa depan. Konstruk pemikiran lahir ini dalam konteks kepentingan politik sebagai langkah antisipasi menyelematkan masa depan pendidikan Islam Indonesia.

${ }^{5}$ Balitbang P\&K, Pendidikan di Indonesia 1900-1974 (Jakarta: Balai Pustaka, 1976), 40-41 Lihat juga Brugmans, "Politik Pengajaran", dalam Baudet dan Brugmans, "Politik Etis dan Revolusi Kemerdekaan (Jakarta: YOI, 1987), 187. Lihat juga Departemen Agama, Perguruan Tinggi Agama Islam di Indonesia: Sejarah Pertumbuhan dan Perkembangan (Jakarta: Departemen Agama Direktorat Jenderal Kelembagaan Agama Islam, 2003), 6.

${ }^{6}$ Departemen Agama, Perguruan Tinggi Agama Islam di Indonesia: Sejarah Pertumbuhan dan Perkembangan (Jakarta: Departemen Agama Direktorat Jenderal Kelembagaan Agama Islam, 2003), 6-7. 


\section{Konteks Keilmuan Lahirnya Perguruan Tinggi Keagamaan}

Keinginan kuat untuk mendirikan pendidikan tinggi keagamaan Islam senantiasa disuarakan. Respon yang paling getol dilontarkan Dr. Satiman Wirjosandjojo yang ditulis di harian Pedoman Masyarakat Nomor 15 Tahun IV pada tahun 1938. Ide ini disambut oleh majalah AID Nomor. 128 tanggal 12 Mei 1938 yang memberitakan bahwa telah diadakan permusyawaratan antara tiga badan pendiri Sekolah Tinggi di Jakarta, Solo, dan Surabaya. ${ }^{7}$ Pada bulan April 1945, empat bulan sebelum proklamasi kemerdekaan Indonesia, sekelompok pemimpin Muslim berkumpul di Jakarta guna membentuk sebuah komisi persiapan yang dipimpin oleh Moh. Hatta. Tugas komisi ini adalah mempersiapkan pembentukan lembaga tinggi Islam yang diwujudkan pada tanggal 8 Juli 1945 dengan berdirinya Sekolah Tinggi Islam. ${ }^{8}$

Setelah kemerdekaan RI, seiring dengan berpindahnya ibukota akibat revolusi dari Jakarta ke Yogyakarta, maka keberadaan Sekolah Tinggi Islam tersebut mengikuti gerak para aktivis Republik. Pada tanggal 10 April 1946, sebuah perguruan Islam berdiri di Yogyakarta dan kemudian beralih status menjadi Universitas Islam Indonesia (UII) pada tanggal 10 Maret 1948. ${ }^{9}$ Akhirnya, pada tanggal 9 Mei 1960 terbitlah peraturan Presiden Nomor 11 Tahun 1960 tentang pembentukan Institut Agama Islam Negeri (IAIN) dengan nama alJamiah al-Islamiyah al-Hukumiyah yang terdiri dari empat fakultas yaitu Ushuluddin, Syariah, Tarbiyah, dan Adab.

Waryani Fajar Rianto menyebutkan empat alasan mendasar dari tulisan Satiman tentang pentingnya mendirikan Sekolah Tinggi Islam. Pertama, kesadaran bahwa masyarakat tertinggal dalam pengembangan pendidikan dibanding non-Muslim. Kedua,

7 A. Hasjmy, Mengapa Umat Islam Mempertahankan Pendidikan Agama dalam Sistem Pendidikan Nasional? (Jakarta: Bulan Bintang, 1979), 31 Lihat juga Amir Hamzah, Wawasan Politik Seorang Muslim Patriot Dr. Soekiman Wirjosandjojo 18981974, (Malang: YP2LPM, 1984), 27-31.

8 Syamsunniam, "Perguruan Tinggi Agama Islam (PTAI) di Tengah Perubahan: Memetakan Problem, Tantangan, dan Prospek PTAI di Era Kapitalisme Global" (Annual Conference on Islamic Studies in Indonesia (ACIS) ke-7, 21 November 2007).

9 Departemen Agama, Perguruan Tinggi Agama Islam di Indonesia: Sejarah Pertumbuhan dan Perkembangan, 12. 
masyarakat non-Muslim maju karena mengadopsi cara Barat dalam sistem pendidikan mereka. Ketiga, perlunya menghubungkan sistem pendidikan Islam dengan dunia internasional. Keempat, dalam pendidikan Islam, unsur lokal penting diperhatikan. ${ }^{10}$

Berbagai alasan itu kemudian menjadi pendorong lahirnya perguruan tinggi keagamaan Islam dengan semangat keilmuan yang kokoh untuk menciptakan lembaga yang kredibel sebagai lokomotif pencerahan dalam tradisi akademik. ${ }^{11}$ Selain itu, transformasi akademik menjadi tumpuan keinginan untuk mengatasi Berbagai ketertinggalan informasi dan pengetahuan.

\section{Kebijakan Negara dalam Pengembangan Perguruan Tinggi Keagamaan}

Dalam sejarah awal berdirinya, perguruan tinggi keagamaan Islamdiwarnai oleh pendekatan kajian normatif-doktrinal yang bertumpu pada satu arah. Implikasinya, kajian keislaman melahirkan wajah Islam yang kaku, teosentris dan sarat dengan dogma. ${ }^{12} \mathrm{Hal}$ ini merupakan implikasi logis dominasi pendekatan yang diadopsi dari sejumlah perguruan tinggi Islam Timur Tengah, utamanya al-Azhar Kairo $^{13}$ yang pernah menjadi imam bagi perguruan tinggi keagamaan di Indonesia. ${ }^{14}$ Pendekatan yang digunakan adalah dikotomi keilmuan yang melahirkan studi hukum Islam normatif, tekstual dan rigid. Sebagaimana ditulis Atho' sebagai berikut:

The above discussion has shown that IAINs are searching for new qiblah (direction) in developing their programs of Islamic studies at both undergraduate and graduate levels. They started

${ }^{10}$ Waryani Fajar Riyanto, Studi Islam Indonesia 1950-2014: Rekonstruksi Sejarah Perkembangan Studi Islam Integratif di Program Pascasarjanaa Perguruan Tinggi Agama Islam (PTAI) (Depok: Kurnia Salam Semesta, 2014), 30-32.

${ }^{11}$ Marwan Salahuddin, "Model Pengembangan Pendidikan Tinggi Islam di Indonesia," Ulumuna: Jurnal Studi Keislaman 18, no. 1 (8 November 2017): 120-21, https://doi.org/10.20414/ujis.v18i1.155.

${ }^{12}$ A. Halil Thahir, "Dari Nalar Literalis-Normatif Menuju Nalar KontekstualisHistoris Dalam Studi Islam," ISLAMICA: Jurnal Studi Keislaman 5, no. 1 (1 September 2010): 1-2, https://doi.org/10.15642/islamica.2010.5.1.1-14.

${ }^{13}$ Michael Laffan, "An Indonesian Community in Cairo: Countinuity and Change in a Cosmopolitan Islamic Milieu," Southeast Asia Program Publication Cornel University 77 (2004): 19-22, http://www.jstor.org/stable/3351417.

${ }^{14}$ M. Atho Mudzhar, Pendekatan Studi Islam Dalam Teori dan Praktik (Yogyakarta: Pustaka Pelajar, 2007), 28. 
with the adoption of the convensional concept of Islamic studies, the old model of Al-Azhar, but as al-Azhar itself has converted into a full fledged university offering all sorts of secular fields of studies, IAINs are beginning to seek the posibility of converting themselves into full fledged universities ar well. ${ }^{15}$

Berbagai kritik muncul terhadap absolutisme pemahaman yang bersifat tunggal di lingkungan perguruan tinggi keagamaan. Kritikkritik tajam muncul dan mengasosiasikan perguruan tinggi keagaman tak ubahnya lembaga dakwah yang hanya memiliki tugas dan peran menyampaikan ajaran agama. Salah satu kritik muncul dari Sudirman Tebba yang menganggap bahwa perguruan tinggi keagamaan gagal dalam pengembangan kajian dan tradisi akademik. ${ }^{16}$

Merespon Berbagai kritik konstruktif, muncul inisiatif dan respon dari pemangku kebijakan perguruan tinggi keagamaan Islam. Respon yang mencul bertumpu pada dua hal. Pertama, terkait menguatnya fenomena pembangunan dan perubahan zaman.Kedua, terkait dengan kompetensi dan peningkatan mutu pendidik di lingkungan perguruan tinggi keagamaan Islam. Yang berkaitan dengan pembangunan dan perubahan, Mukti Ali hendak meyesuaikan dengan perkembangan yang terjadi. ${ }^{17}$ Dalam konteks itu, modernisasi perguruan tinggi keagamaan Islam menjadi hal yang niscaya untuk dilakukan sebagai pemangku kebijakan yang diharapkan dapat mengubah wajah perguruan tinggi keagamaan Islam. ${ }^{18}$ Dalam konteks program pembangunan nasional yang mengambil modernisasi sebagai tujuannya, para intelektual Muslim

${ }^{15}$ M. Atho Mudzhar, "Islamic Studies in Indonesia in The Making", a paper presented at the International Conference on Islam in Indonesia: Intellectual and Social Transformation, held by Ministry of Religious Affairs Republic of Indonesia in Cooperation with McGill University Canad, November, 23-24, (2000), 4; Islam and Islamic Law in Indonesia: A Socio-Historical Approach (Jakarta: Religious Research and Development and Training, 2003), 90.

${ }^{16}$ Sudirman Tebba, Orientasi Mahasiswa dan Kajian Islam IAIN," dalam Islam Orde Baru (Yogyakarta: Tiara Wacana, 1993), 183-92.

${ }^{17}$ Khoirun Niam, "Muslim Intellectual in The Twentieth Century Indonesia: A Socio-Political and Educational Context," Journal of Indonesian Islam 2, no. 1 (1 Juni 2008): 43-44, https://doi.org/10.15642/JIIS.2008.2.1.39-68.

18 Muhammad Amin Abdullah, "Islamic Studies in Higher Education in Indonesia: Challenges, Impact and Prospects for the World Community," AlJami'ah: Journal of Islamic Studies 55, no. 2 (2017): 403-4, https://doi.org/10.14421/ ajis.2017.552.391-426. 
Indonesia, termasuk Menteri Agama kali itu Mukti Ali ${ }^{19}$, Harun Nasution $^{20}$, dan Nurcholish Madjid ${ }^{21}$ mengambil peran dan kiprah yang cukup signifikanuntuk mereorientasi arah kajian Islam yang berlangsung di perguruan tinggi keagamaan.

\section{Sementara yang berkaitan yang pengembangan mutu} akademik, Mukti Ali mengirimkan para intelektual muda Muslim ke Barat untuk meneruskan jenjang studinya. Sejak menjabat sebagai Menteri Agama pada tahun 1971-1978, Departeman Agama

19 Mukti Ali menegaskan perlunya memperkenalkan pendekatan yang empiris atas Islam sebagai jalan untuk menafsirkan ulang khazanah pemikiran Islam dalam konteks keindonesiaan dan modernitas. Mukti Ali pada tahun 1960 di IAIN telah memperkenalkan Ilmu Perbadingan Agama. Ia adalah orang pertama yang berhasil memperoleh gelar Master of Arts dengan tesis berjudul Mukti Ali, "The Muhammadiyah Movement: A Bibliographical Introduction" (Tesis, Mc Gill, 1957); Dalam konteks pengembangan studi Islam, Mukti Ali pernah menulis buku Mukti Ali, Memahami Beberapa Aspek Ajaran Islam, 1991. Lihat Ali Munhanif, "Prof Dr. Mukti Ali: Modernisasi Politik-Keagamaan Orde Baru," in Menteri-Menteri Agama RI: Biografi Sosial Politik, ed. oleh Azyumardi Azra dan Saiful Umam (Jakarta: PPIM IAIN Jakarta dan Litbang Depag, 1998). Lihat Juga Ali Munhanif, 281. Lihat juga Mukti Ali, Mukti Ali, Beberapa Persoalan Agama Dewasa Ini (Jakarta: Rajawali, 1987). Bandingkan Mukti Ali, "Penelitian dan Pengembangan Ilmu Pengetahuan Agama Islam," in Pengantar ke Arah Metode Penelitian dan Pengembangan Ilmu Pengetahuan Agama Islam, ed. oleh M Masyhur Amin (Yogyakarta: P3M IAIN Sunan Kalijaga, 1992).

20 Karya-karya Harun Nasution cukup signifikan empengaruhi pola pemikiran intelektual perguruan tinggi keagamaan khususnya di IAIN Syarif Hidayatullah. Konstruk pemikiran pembaruan yang diperkenalkan kemudian mendorong dan menginspirasi beberapa sarjana perguruan tinggi keagamaan untuk mendalami dan mengkaji, yang jika ditelisik lebih mendalam, menginspirasi mereka untuk melanjutkan pendidikan ke Barat. Harun pernah memimpin IAIN Syarif Hidayatullah Jakarta dan menjadi Direktur Program Pascasarjana. Karya Harun Nasution digunakan sebagai literatur wajib bagi mahasiswa IAIN. Ia alumni dari pendidikan luar negeri dalam bidang Studi Islam. Harun merupakan generasi pertama yang meletakkan landasan berteologi secara kritis-rasional terhadap doktrin-doktrin akidah Islam. Ia pula yang secara terang-terangan memproklamirkan diri sebagai pendukung utama aliran Mu'tazilah dalam berteologi yang senantiasa mengedepankan proses berpikir rasional. Lihat Richard Martin, "Harun Nasution and Modern Mu'tazilism," in Defenders of Reason in Islam (Oxford: Oneworld, 1997), 119-79.

${ }^{21}$ Nurcholis Madjid sangat kritis terhadap pelbagai permasalahan sosial keagamaan bangsa Indonesia. Setelah menyelesaikan program doktor di Universty of Chicago pada tahun 1984 dengan judul disertasinya Nurcholis Madjid, "Ibn Taymiya on Kalam and Falsafah: A Problem of Reason and Revelation in Islam" (Dissertation, Universty of Chicago, 1984), ia menjadi salah seorang intelektual Islam Indonesia. Ada empat strategi pemikiran Nurcholish Madjid tentang integrasi yaitu Integrasi Islam dan Kemanusiaan, kemodernan, politik dan keindonesiaan. Lihat Muhammad Wahyuni Nafis, Cak Nur sang Guru Bangsa; Biografi Pemikiran Prof. Dr. Nurcholish Madjid (Jakarta: Kompas, 2014); ]. Bandingkan Faisal Ismail, Sekularisasi: Membongkar Kekeliruan Pemikiran Nurcholish Madjid (Yogyakarta: Nawasea Press, 2008]. 
menjalin kerjasama dengan McGill University, Canada. Pengiriman dosen-dosen IAIN ke McGill University adalah bagian dari upaya modernisasi perguruan tinggi keagamanIslam menjadi lembaga kajian akademis. ${ }^{22}$ Sejak tahun 1989, Departemen Agama menjalin kerja sama dengan McGill University dan telah meluluskan lebih dari 100 intelektual perguruan tinggi keagamaan Islam baik dalam program kursus singkat maupun studi Magister atau Doktor.

Keterbukaan intelektual di perguruan tinggi keagamaan Islam terhadap gerakan pembaruan diperkuat oleh kebijakan promodernisasi dan akomodatif yang diterapkan oleh negara, yang dalam hal ini dibawah komando Menteri Agama Mukti Ali. McVey menyebut bahwa Departemen Agama berusaha menjembatani jurang antar kaum santri dan negara dengan memberi Islam juru bicara yang dapat berkomunikasi secara mudah dengan rezim dan memiliki persepsi yang sama. ${ }^{23}$

\section{E. Pergeseran Kiblat Keilmuan Perguruan Tinggi Keagamaan}

Sebagaimana disebutkan di atas, bahwa kajian akademik pada mulanya di perguruan tinggi keagamaan Islam berkiblat pada lembaga-lembaga di Timur Tengah. Dalam konteks ini, Yudi Latif telah mengetengahkan pola pergeseran kiblat kajian akademik perguruan tinggi keagamaan Islam. Nurcholish Madjid menjadi salah satu "imam besar" yang dijadikan kiblat keilmuan di lingkungan perguruan tinggi keagamaan Islam yang berpengaruh terhadap pengembangan rasa percaya diri komunitas intelektual perguruan tinggi keagamaan Islam. Ide-ide pembaruannya menjadi pemandu bagi generasi intelektual perguruan tinggi keagamaan Islam. Perjalanan studinya di University Chicago, menjadi inspirasi bagi banyak sarjana untuk belajar di pusat-pusat studi Islam di Barat.

${ }^{22}$ Margaret menulis sebuah misi pendek tentang kerjasama pengembangan IAIN antara Institute of Islamic Studies McGill University, Canada dan Departemen Agama. Fragmen menarik yang ditampilkan adalah pergulatan pemikiran kaum modernis yang lahir dari Universitas di Barat seperti McGill yang kemudian membawa pemikiran modernis-progresif dengan basis sekularisme vis a vis Islamisme. Margaret Gillet, "The IAIN in Indonesian Higher Education," Muslim Education Quarterly 8, no. 1 (1990): 21-26.

${ }^{23}$ R.T. MCVey, Faith as The Outsider: Islam in Indonesia politic's in Islam in The Political Process, ed. J. P. Piscatori (Cambridge: Cambridge University Press, 1989), 199-221. 
Dampak langsung dukungan pemerintah adalah terjadinya pergeseran dalam tujuan studi pascasarjana di lingkungan perguruan tinggi keagamaan Islam. Pergeseran itu terkonfirmasi dengan perubahan dari pusat-pusat studi Islam di Timur Tengah ke pusatpusat studi Islam di Barat. Hingga akhir tahun 1960-an, hanya sedikit sarjana Indonesia bertalar belakang pendidikan Islam yang menempuh studi Islam di universitas-universitas Barat. Di antara mereka yang sedikit itu adalah H.M Rasjidi (meraih gelar Ph.D dari Sorbonne University, Perancis), Mukti Ali dan Anton Timur Djaelani (meraih gelar Master dari McGill University Canada masing-masing pada tahun 1957 dan 1959), Harun Nasution (mendapat gelar Ph.D dari McGill University Kanada, 1968), dan Kafrawi (meraih gelar Master dari McGill University Kanada, 1969). ${ }^{24}$ Sejak tahun 1970-an hingga sekarang, arus sarjana-sarjana perguruan tinggi keagamaan untuk melanjutkan studi ke universitas di Barat berlipat ganda dan terus bertambah didorong dengan program-program beasiswa baik yang berasal dari Kementerian Agama ataupun beasiswa lainnya. Mereka yang kembali dari universitas Barat ini kemudian memiliki peran yang cukup signifikan dalam pengembangan kajian dan tradisi akademik di lingkungan perguruan tinggi keagamaan Islam. Reorientasi kajian yang lebih terbuka dengan gagasan-gagasan cemerlang tumbuh dan menginspirasi kepada sarjana lainnya. Ide-ide pembaruan dan konstruk pemikiran yang lebih terbuka menjadi diskursus baru di lingkungan perguruan tinggi keagamaan Islam yang kemudian menginspirasi ide, gagasan, statement, karya dan sensivitas antropologis bagi sarjana lain di perguruan tinggi keagamaan seluruh Indonesia.

Dalam konteks kebijakan saat ini, Kementerian Agama dengan program 5000 Doktor mengirimkan puluhan sarjana perguruan tinggi keagamaan Islam untuk studi di Berbagai universitas kenamaan luar negeri. Program ini diharapkan dapat menumbuhkan tradisi akademik yang tinggi dalam percaturan wacana keilmuan yang kritis, transformatif dan terbuka terhadap Berbagai disiplin keilmuan.

${ }^{24}$ Yudi Latif, Genealogi Intelegensi: Pengetahuan dan Kekuasaan Intelkegensia Muslim Indonesia Abad XX (Jakarta: Kencana Prenadamedia Group, 2012), 501. 


\section{F. Peningkatan Tradisi Akademik dan Ledakan Doktor Alumni Luar Negeri}

Pembentukan jaringan keilmuan dalam pengembangan tradisi akademik di perguruan tinggi keagamaan Islambukanlah sesuatu yang datang secara tiba-tiba. Dalam proses itu terdapat keterkaitan dan kesinambungan dengan perkembangan pemikiran yang ditandai dengan dialektika keilmuan dan ditopang oleh berbagai kebijakan dari negara. Dalam konteks ini, kuasa beroperasi di seputar dan melalui jejaring yang tumbuh di sekeliling institusi-institusi negara. ${ }^{25}$

Michel Foucault mengokohkan kuasa adalah pengetahuan (power is knowledge) dengan dalih bahwa di era kontemporer ini kuasa akan sesuatu bisa berimplikasi pada wacana yang berkembang di masyarakat. ${ }^{26}$ Sementara pendidikan dan kuasa adalah dua elemen penting dalam sistem sosial politik di setiap negara, baik negara maju maupun negara berkembang. Pendidikan dan kuasa memiliki pengaruh kuat dalam proses pembentukan karakteristik masyarakat di suatu negara. Lembaga-lembaga dan proses politik di suatu negara memberikan dampak besar pada karakteristik pendidikan suatu negara.Dalam konteks pendidikan di Indonesia memang tidak bisa terlepas dari knowledge and power (pengetahuan dan kuasa). Kuasa dapat menjadi penanda dari lahirnya pengetahuan yang konstruksi dengan Berbagai intervensi kebijakan politik untuk mengubah arah dan haluan kajian akademik di perguruan tinggi keagamaan Islam. Hal ini menjadi keniscayaan mengingat pengetahuan dapat diperoleh melalui pendidikan dan kuasa yang diemban oleh pemerintah untuk mengatur dan menentukan perkembangan peradaban bangsa Indonesia.

Penguatan tradisi akademik di perguruan tinggi keagamaan Islam juga tidak bisa dilepaskan dari kuasa negara dalam kerangka pencarian format yang tepat untuk memberikan Berbagai tawaran program dalam pengembangan keilmuan. Konstruks studi Islam di perguruan tinggi keagamaan Islam yang pada awalnya terkotakkan pada studi Islam normatif kemudian mengalami pergeseran pada

\footnotetext{
${ }^{25}$ S. Mills, Discourse (London: Routledge, 1999), 31.

${ }^{26}$ Michel Foucault, The Archeology of Knowledge (London: Tavistock, 1972), 128.
} 
kajian integratif setelah mengawinkan Berbagai pendekatan. ${ }^{27}$ Pendekatan ini mulai diperkenalkan oleh sarjana-sarjana perguruan tinggi keagamaan Islam yang telah menyelesaikan pendidikan di luar negeri, utamanya di Barat.

Di lingkungan perguruan tinggi keagamaan Islam pada awal tahun 1970, membicarakan penelitian tentang agama masih dianggap tabu. Wacana pemikiran keagamaan normatif yang bertumpu pada teks mendominasi diskursus yang berkembang. ${ }^{28}$ Lebih dari itu, pengembangan ilmu-ilmu keagamaan juga masih berputar pada level dogmatis-normatif yang ditandai dengan Fakultas Syariah, Ushuludin, Adab dan Tarbiyah dalam bingkai pemahaman teologis yang diperkenalkan oleh para alumni timur tengah yang muncul pada periode 1950-an hingga tahun 1970-an. Memasuki pertengahan tahun 1970, tradisi tersebut mulai bergeser dengan ditandai para sarjana IAIN yang belajar ke Barat. ${ }^{29}$

Dalam sejarahanya, era tahun 1950 hingga tahun 1970, secara umum corak atau kecendrungan kajian Islam di lingkungan perguruan tinggi keagamaan Islam bersifat normatif. Pendekatan yang digunakan bertumpu pada teks dan kemudian berhenti pada kemanunggalan tafsir. Hal ini berbeda dengan dekade tahun 1970an yang lebih mengarah kepada kajian Islam yang terkait dengan konteksnya, bersifat sosio-kultural yang menyejarah. Barometer gerakan pembaruan itu menemukan momentum awal dimana mulai muncul tokoh-tokoh intelektual Islam seperti H.M Rasjidi, Mukti Ali, Harun Nasution, Nurcholis Madjid mereorientasi arah kajian

${ }^{27}$ Noorhaidi Hasan, "Meretas Involusi Kajian Hukum Islam di Indonesia: Pengalaman Fakultas Syariah dan Hukum UIN Sunan Kalijaga Yogyakarta," . 46, no. 2 (1 Juli 2012): 387-99, https://doi.org/10.14421/asy-syir'ah.2012.\%x.

${ }^{28}$ Musahadi, “Islam sebagai Sasaran Studi: Indentifikasi Awal terhadap Problem, Pola, dan Pendekatan Studi Islam di Indonesia" (Proceeding ACIS V, 2005), 235.

${ }^{29}$ Carool Kersten, Berebut Wacana: Pergulatan Wacana Umat Islam Indonesia Era Reformasi (Bandung: Mizan, 2018), 42 Kersten membahas kebangkitan pembaruan pemikiran Islam yang cenderung merangkul Muslim terpelajar untuk berperan dalam strategi politik pemerintahan. Program pembangunan nasional kemudian melahirkan perancang arah baru Indonesia dari kaum intelektual Muslim kalangan perguruan tinggi keagamaan Islam seperti Harun Nasution (1919-1998), Mukti Ali (1923-2004), dan Nurcholish Madjid (1939-2005), dan generasi setelahnya yaitu M. Amin Abdullah dan Azyumardi Azra sebagai punggawa mazhab Yogya dan mazhab Ciputat. 
Islam di IAIN. ${ }^{30}$ Proses ini kemudian membawa pertarungan wacana dalam dalam diskursus kajian yang menjadikan lembaga perguruan tinggi keagamaan Islam sebagai basis utamanya. Di Jakarta, Berbagai kegiatan dan diskusi diselenggarakan di kampus IAIN Syarif Hidayatullah Jakarta dengan komando Harun Nasution dan beberapa alumni luar negeri seperti Azyumardi Azra, Komaruddin Hidayat, Mulyadi Kartanegara, dan generasi selanjutnya Saiful Mujani, Ali Munhanif, Fuad Jabali, Dadi Darmadi, Ismatu Ropi dan lainnya. Sementara di Yogyakarta, basis pengetahuan dan diskusi dilakukan di lingkungan kampus IAIN Sunan Kalijaga dengan beberapa komando alumni luar negeri.

Di satu sisi, perkembangan kajian keislaman juga didukung dengan arus kebijakan pemerintah mengirimkan para sarjana untuk belajar ke luar negeri dan menjadi penanda awal terbukanya iklim akademik di lingkungan perguruan tinggi keagamaan Islam. ${ }^{31}$ Sejak saat itu sejumlah lulusan terbaik di IAIN mulai meninggalkan tanah air untuk melanjutkan studi di luar negeri.

Setelah kebijakan itu diterapkan oleh Menteri Agama Munawir Syadzali dengan segala program yang disusun hingga akhirnya menjadi pilot project prioritas program kerja. Hasilnya, perlahan dapat dirasakan setelah para alumni menyelesaikan studinya. ${ }^{32}$

${ }^{30}$ Syamsun Ni'am, “Reformulasi Paradigma Kajian Keislaman di Perguruan Tinggi Agama Islam", dalam Proceeding ACIS IX" (2009), 125.

31 Arus pendidikan mahasiswa Islam ke Barat tidak dapat dilepaskan dari kebijakan Departemen Agama RI yang mulai melakukan kerjasama-kerjasama dengan perguruan tinggi Barat. Kebijakan ini sebenarnya pernah dirintis oleh Mukti Ali ketika menjadi Menteri Agama meskipun belum menampakkan hasil yang memuaskan. Ketika Munawir Syadzali menjabat Menteri Agama selama dua periode (1983-1993), ia banyak membuat kerjasama dengan universitas-universitas di Barat seperti McGill University Canada, Leiden University Belanda, UCLA, Columbia University, Chicago dan beberapa kampus di Australia. Dengan kerjasama ini, banyak sekali dosen-dosen IAIN dari pelbagai latar belakang keilmuan yang belajar di universitas-universitas di Barat. Untuk lebih lengkap, lihat "An Intellectual Engineering in IAIN," Studia Islamika 2, no. 1 (n.d.).

32 Para sarjana IAIN yang lulus dari McGill University Canada, selain Mukti Ali dan Harun Nasution, antara lain Anton Timur Jaylani (1959), Tedjaningsih Djaylani (1959), Mochtar Naim (1960), dan Kafrawi Ridwan (1969), masing-masing memperoleh ijazah S2. Selanjutnya, pada awal 1970-an, kedatangan sembilan orang sarjana Muslim Indonesia untuk meneruskan studi Pascasarjana di Montreal, mewarnai diskursus kajian keislaman yang masing-masing menulis tentang kajian Islam di Indonesia yaitu A. Hafidz Dasuki (1974), Zaini Muhtarom (1975), Murni Jamal (1975), Muhammad Idris (1975), Nourozzaman Shiddieqy (1975), Bisri Afandi 
Akhir dekade 1980-an, saat Menteri Agama dijabat oleh Munawir Syadzali, ia menyelenggarakan Program Pembibitan Calon Dosen IAIN se-Indonesia. Program tersebut dipersiapkan untuk mengirim dosen-dosen muda IAIN dari seluruh Indonesia untuk belajar ke Barat, seperti Kanada, Amerika Serikat, Australia, Inggris, Jerman, Turki, dan lainnya. Maka pada tahun 1985, Amin Abdullah dan Komaruddin Hidayat belajar di Turki. Tahun 1986 menyusul M. Atho Mudzhar, Din Syamsudin, Toha Hamim, Mulyadi Kartanegara, A. Qodri Azizy, Azyumardi Azra, Kautsar Azhari Noer, Hamdani Anwar, Nurul Fajri, Nurlena, Sri Mulyani, Jaenuri, dan lain sebagainya. Program pembibitan calon dosen juga menghasilkan alumni luar negeri seperti Hasan Asyari, Akh. Minhaji, Fauzan Saleh, Yudian Wahyudi, M. Nafis, Faisal Ismail, Andi Faisal Bakti, dan beberapa doktor alumni luar negeri lainnya seperti Masykuri Abdillah, Abdurrahman Mas'ud, Nur Fadhil Lubis dan lainnya. ${ }^{33}$ Saat ini, generasi tahun 90-an sudah menjadi pimpinan di Berbagai perguruan tinggi keagamaan. Di UIN Sunan Kalijaga Yogyakarta, rektor saat ini Yudian Wahyudi merupakan alumni program pembibitan Dosen Departemen Agama dan kemudian melanjutkan studi ke luar negeri. Begitu juga dengan Direktur Pascasarjana UIN Yogyakarta saat ini, Noorhaidi Hasan yang menyelesaikan jenjang Magister dan Doktornya di luar negeri (Belanda). Di UIN Sunan Ampel Surabaya, Masdar Hilmy yang merupakan alumni dari program pembibitan dosen dan menyelesaikan program Magister dan Doktor di luar negeri, saat ini telah menjadi rektor. Kampus UIN Antasari Banjarmasin juga dipimpin oleh alumni pembibitan dosen dan juga alumni dari perguruan tinggi di Barat (Belanda) yaitu Mujiburrahman. Bahkan, Direktur Jenderal Pendidikan Islam Kementerian Agama saat ini, Kamarudin Amin juga merupakan salah satu alumni program pembibitan dosen dan meraih gelar Master dan Doktor dari universitas di luar negeri. Sama halnya dengan Direktur Pendidikan Tinggi Keagamaan Islam Kementerian Agama saat ini,

(1976), Saifuddin Anshori (1976), A. Farichin Chumaidy (1976), Muhammad Asyari (1976), dan Iik Arifin Mansurnoor (1987). Lihat Fuad Jabali, IAIN dan modernisasi Islam di Indonesia (Logos Wacana Ilmu, 2002), 24.

${ }^{33}$ Waryani Fajar Rianto, Studi Islam Indonesia (1950-2014): Rekonstruksi Sejarah Perkembangan Program Studi Islam Integratif di Program Pascasarjana Perguruan Tinggi Agama Islam (Yogyakarta: Kurnia Alam Semesta, 2014), 83. 
Arskal Salim juga merupakan alumni pendidikan di luar negeri yaitu Australia (Melbourne University). Hal ini menunjukkan bahwa politik program kebijakan pengiriman dosen ke luar negeri saat ini telah menemukan bukti dan hasil yang sangat menggembirakan.

Ledakan alumni doktor luar negeri ini menjadi penanda semakin berkembangnya wacana intelektual di lingkungan perguruan tinggi keagamaan Islam dengan diwarnai semangat tradisi akademik dan intelektual yang lebih terbuka, kritis, dan progresif. Ledakan doktor alumni luar negeri ini kemudian menjadi lokomotif perkembangan tradisi akademik di masing-masing perguruan tinggi keagamaan Islam, misalnya Azyumardi Azra, Din Syamsudin, Bakhtiar Efendy, Komaruddin Hidayat, Masykuri Abdillah, Mulyadi Kartanegara, Fuad Jabali,Ali Munhanif, Arskal Salim, Asep Saepudin Jahar, dan akademisi lainnya (UIN Syarif Hidayatullah Jakarta), Amin Abdullah, Atho Mudzhar, Akh. Minhaji, Faisal Ismail, Yudian Wahyudi, Noorhaidi Hasan, Moh. Nur Ichwan, dan akademisi lainnya (UIN Sunan Kalijaga Yogyakarta), Syafiq Muhni, Thoha Hamim, Masdar Hilmy (UIN Sunan Ampel Surabaya), dan A. Qodri Azizy dan Abdurrahman Mas'ud (UIN Walisongo Semarang). ${ }^{34}$ Dalam bidang pemikiran kesilaman, para tokoh-tokoh inilah yang kemudian menjadi pijakan dan referensi dosen dalam melakukan penelitian dan kajian studi Islam di perguruan tinggi keagamaan Islam.

Dalam konteks ini, kajian-kajian pemikiran keislaman di perguruan tinggi keagamaan Islam diwarnai dua arus besar intelektualisme (Timur Tengah dan Barat) yang pada gilirannya membentuk corak pemikiran tertentu. Hal ini disebakan oleh cara pandang berpikir yang sebagai besar doktor alumni luar negeri dimulai dari pendidikan di pesantren dengan pembelajaran normatif. Saat mereka belajar di Barat, memungkinkan untuk melakukan refleksi kritis atas tradisi keberagamaannya. Pendidikan dasarnya dibesarkan dari kaki pesantren, namun pemikirannya cukup kritis dengan menggunakan Berbagai kajian integratif. ${ }^{35}$ Para dosen di perguruan

${ }^{34}$ Dadi Darmadi, "IAIN dalam Wacana Intelektual Islam Indonesia", dalam Komaruddin Hidayat dan Hendro Prasetyo, Problem dan Prospek IAIN: Antologi Pendidikan Tinggi Islam (Jakarta: Departemen Agama RI, 2000), 340.

${ }^{35}$ Kajian integratif di lingkungan perguruan tinggi keagamaan Islam dapat dilihat dalam studi hukum Islam di UIN Sunan Kalijaga Yogyakarta. Pendekatan yang digunakan tidak hanya bertumpu pada satu aspek kajian, melainkan menggunakan 
tinggi keagamaan Islam berani mendiskusikan hal-hal yang selama ini dianggap sebagai sesuatu yang tabu untuk diperbincangkan, lalu kemudian tumbuh pikiran kritis untuk didiskusikan. Ajaran-ajaran doktriner diperbaharui dengan kajian dan metodologi baru. Perubahan ini berjalan melalui tradisi nalar intelektual sebagai basis transformasi dalam mengkaji dan menganalisis persoalan kontemporer.

Tradisi akademik kemudian lahir dalam semarak kajian yang berhasil menampilkan gagasan dan ide-ide cemerlang tentang pemikiran Islam di perguruan tinggi keagamaan Islam. Lahirnya wacana pembaruan dalam kajian studi Islam di perguruan tinggi keagamaanIslam yang kemudian melahirkan doktor-doktor luar negeri merupakan kebijakan dari negara melalui program peningkatan mutu akademik dengan mengirimkan sarjana-sarjana perguruan tinggi untuk melanjutkan studi di luar negeri, utamanya di Barat. Kebijakan ini menjadi sangat strategis yang saat ini bisa dirasakan sebagai kontribusi pengetahuan dan menemukan diskursus dominan yang pada gilirannya merefleksikan apa yang disebut Eyerman dan Jamison sebagai minat pengetahuan (knowledge interest) dari suatu generasi intelektual tertentu. Minat pengetahuan bisa didefinisikan sebagai jenis pengetahuan yang terbentuk dalam konteks sebuah generasi intelektual tertentu. ${ }^{36}$ Burke juga memandang bahwa minat pengetahuan akan melahirkan ide-ide yang tersituasikan (situated) secara sosial dan dibentuk oleh pandangan dunia (world views) atau gaya-gaya pemikiran (styles of thought) dan dibentuk oleh tradisi yang dilembagakan. ${ }^{37}$

Historisitas dan kompleksitas perkembangan pemikiran kajiankeislaman (Islamic Studies) yang ditumbuhkan oleh dosen-dosen perguruan tinggi keagamaan Islam sejatinya telah mengantarkan dalam kerangka pencarian format yang tepat bagi pengembangan pemikiran Islam dengan bingkai desiminasi ide-ide kritis, konstruktif dan historis. Karya mereka menyebar membentuk arkeologi ilmu

pelbagai aspek pendekatan dalam pola dan konstruk analisis kajiannya. Lihat Waryani Fajar Riyanto, "Mazhab Sunan Kalijaga (Refleksi Setengah Abad Genealogi Epistimologi Studi Hukum Islam Integratif di Fakultas Syariah UIN Sunan Kalijaga: 1963-2013," Asy-Syir'ah: Jurnal Ilmu Syariah dan Hukum, 47, no. 2 (2013).

${ }^{36}$ R. Eyerman dan A. Jamison, Social Movement: A Cognitive Approach, 129-30.

${ }^{37}$ P. Burke, A Social History of Knowledge: From Gutenberg to Diderot (Cambridge: Cambridge University Press, 2000), 70. 
pengetahuan. Terbentuknya teks-teks yang ditulis menitikberatkan pada proses terbentuknya ide-ide, pengetahuan dan pemikiran yang terus dilestarikan sebagai tradisi akademik. Dari tradisi akademik inilah, perubahan-perubahan muncul, misalnya dari pembacaan pemikiran Islam tekstual menuju kontekstual, dari pendekatan mazhabi ke pendekatan interpretasi, dari normatif ideologis ke kritiskonstruktif, dan Berbagai bentuk lainnya. ${ }^{38}$ Pada titik ini, kuasa politik erat kaitannya dengan pembentukan pengetahuan yang dalam hal ini dapat ditemukan dalam konstruk kajian pemikiran keislaman di perguruan tinggi keagamaan Islam.

Kebijakan politik dengan Berbagai program yang dicanangkan Departemen Agama telah membangkitkan semarak tradisi akademik dengan kajian-kajian studi Islam yang berlangsung dari tahun 1960 sampai 1970 ini dengan perubahan kajian akibat perkembangan ilmu pengetahuan dan teknologi di era globalisasi yang diikuti munculnya persoalan-persoalan baru dimana perguruan tinggi keagamaan Islam dituntut kontribusinya untuk memecahkan persoalan-persoalan secara cerdas dan kreatif. Perguruan tinggi keagamaan Islam antara lain dituntut untuk memperbaiki dan mengembangkan paradigma keilmuan yang lebih komprehensif dan adaptif. Dari segi ini, ilmuilmu keislaman klasik yang awalnya dijadikan mata kuliah di perguruan tinggi keagamaan Islam kemudian dilengkapi dengan ilmu-ilmu sosial keislaman. Tidak hanya pengembangan mata kuliah, namun juga kajiannya perlu diperluas dengan mengintegrasikan Berbagai disiplin keilmuan, seperti sejarah, bahasa, ilmu dakwah, perbandingan agama, filsafat, antropologi, dan disiplin keilmuan lainnya. ${ }^{39}$ Selain itu, juga didukung oleh kebijakan pemerintah dalam transformasi kelembagaan dengan memperluas mandat keilmuan. Melalui model pendekatan integratif yang diinisiasi oleh intelektual akademik perguruan tinggi keagamaanIslam yang didominasi alumni luar negeri, bidang-bidang kajian yang dikembangkan menjadi lebih

38 Khoirul Huda, "Fenomena Pergeseran Konflik Pemikiran Islam dari Tradisionalis vs Modernis ke Fundamentalis vs Liberalis," ISLAMICA: Jurnal Studi Keislaman 3, no. 2 (2 Maret 2009): 22, https:/ / doi.org/10.15642/islamica.2009.3.2.20-42.

${ }^{39}$ Simuh, "Pembidangan Ilmu Agama Islam" dalam Iskandar Zulkarnain, Pembidangan Ilmu Agama Islam pada Perguruan Tinggi Agama Islam di Indonesia (Yogyakarta: P3M IAIN Sunan Kalijaga, 1995), 7. 
luas. Pendekatannya tidak lagi bersifat teologis dan normatif saja, tetapi sekaligus bersifat historis dan sosiologis.

\section{G. Simpulan}

Kebijakan politik dengan pencangan program-program penguatan akademik telah membawa pergeseran kajian pemikiran studi Islam di perguruan tinggi keagamaan Islam. Faktor politik pemilihan kebijakan yang mulai digelotorkan sejak A. Mukti Ali menjabat Menteri Agama dan dilanjutkan Munawir Syadzali telah mampu mendorong penyegaran pengembangan keilmuan keislaman sesuai dengan perkembangan ilmu dan teknologi mutakhir sehingga dapat memperkuat dan meningkatkan kualitas serta produktivitas dosen di lingkungan perguruan tinggi keagamaan Islam.

Tradisi akademik muncul dengan segala indikatornya, misalnya dari pembacaan pemikiran Islam tekstual menuju kontekstual, dari pendekatan mazhabi ke pendekatan interpretasi, dari normatif ideologis ke kritis-konstruktif, dan Berbagai bentuk lainnya. Pada titik ini, kuasa politik erat kaitannya dengan pembentukan pengetahuan yang dalam hal ini dapat ditemukan dalam konstruk kajian pemikiran keislaman di perguruan tinggi keagamaan Islam.

Ke depan, dalam rangka mempersiapkan sumberdaya perguruan tinggi keagamaan Islam yang berkualitas dan memiliki daya saing internasional melalui pendidikan tinggi, pemerintah terus berusaha meningkatkan kualitas dan kualifikasi dosen. Dalam konteks ini, berdasarkan UU RI Nomor 14 tahun 2005, setidaknya ada dua hal yang sangat penting dilakukan, yaitu, (1) meningkatkan dan mengembangkan kompetensi dosen secara terus menerus; dan (2) memberi kesempatan dosen untuk mendapatkan akses ke sumber belajar, informasi, sarana dan prasarana pembelajaran, serta penelitian dan pengabdian kepada masyarakat[.] 


\section{REFERENSI}

A. Halil Thahir. "Dari Nalar Literalis-Normatif Menuju Nalar Kontekstualis-Historis Dalam Studi Islam." ISLAMICA: Jurnal Studi Keislaman 5, no. 1 (1 September 2010): 1-14. https://doi. org/10.15642/islamica.2010.5.1.1-14.

A. Hasjmy. Mengapa Umat Islam Mempertahankan Pendidikan Agama dalam Sistem Pendidikan Nasional? Jakarta: Bulan Bintang, 1979.

Ali Munhanif. "Prof Dr. Mukti Ali: Modernisasi Politik-Keagamaan Orde Baru." In Menteri-Menteri Agama RI: Biografi Sosial Politik, diedit oleh Azyumardi Azra dan Saiful Umam. Jakarta: PPIM IAIN Jakarta dan Litbang Depag, 1998.

“An Intellectual Engineering in IAIN." Studia Islamika 2, no. 1 (n.d.).

Balitbang P\&K. Pendidikan di Indonesia 1900-1974. Jakarta: Balai Pustaka, 1976.

Carool Kersten,. Berebut Wacana: Pergulatan Wacana Umat Islam Indonesia Era Reformasi. Bandung: Mizan, 2018.

David Easton. Understanding Public Policy, dalam AG. Subarsono, Analisis Kebijakan Publik, Konsep, Teori dan Aplikasi. Yogyakarta: Pustaka Pelajar, 2000.

Departemen Agama. Perguruan Tinggi Agama Islam di Indonesia: Sejarah Pertumbuhan dan Perkembangan. Jakarta: Departemen Agama Direktorat Jenderal Kelembagaan Agama Islam, 2003.

Faisal Ismail. Sekularisasi: Membongkar Kekeliruan Pemikiran Nurcholish Madjid. Yogyakarta: Nawasea Press, 2008.

Farid Abdul Khalik. Al-Figh al-Siyasy al-Islamy: Mabadi' Dusturiyah alSyura al-'Adl al-Musawa. Beirut: Dar al-Fikr, 1991.

Frederick M Denny. "Component of Religion: The Case of Islam." Oxford Journals: OAH Magazine of History 6, no. 3 (1992).

Iskandar Zulkarnain. Pembidangan Ilmu Agama Islam pada Perguruan Tinggi Agama Islam di Indonesia. Yogyakarta: P3M IAIN Sunan Kalijaga, 1995.

Jabali, Fuad. IAIN dan modernisasi Islam di Indonesia. Logos Wacana Ilmu, 2002. 
Khoirul Huda. "Fenomena Pergeseran Konflik Pemikiran Islam dari Tradisionalis vs Modernis ke Fundamentalis vs Liberalis." ISLAMICA: Jurnal Studi Keislaman 3, no. 2 (2 Maret 2009): 20-42. https://doi.org/10.15642/islamica.2009.3.2.20-42.

Khoirun Niam. "Muslim Intellectual in The Twentieth Century Indonesia: A Socio-Political and Educational Context." Journal of Indonesian Islam 2, no. 1 (1 Juni 2008): 39. https://doi. org/10.15642/JIIS.2008.2.1.39-68.

Komaruddin Hidayat, dan Hendro Prasetyo. Problem dan Prospek IAIN: Antologi Pendidikan Tinggi Islam. Jakarta: Departemen Agama RI, 2000.

M. Atho Mudzhar. "Islamic Studies in Indonesia in The Making", a paper presented at the International Conference on Islam in Indonesia: Intellectual and Social Transformation, held by Ministry of Religious Affairs Republic of Indonesia in Cooperation with McGill University Canad, November, 23-24, (2000), 4; Islam and Islamic Law in Indonesia: A Socio-Historical Approach. Jakarta: Religious Research and Development and Training, 2003.

------.Pendekatan Studi Islam Dalam Teori dan Praktik. Yogyakarta: Pustaka Pelajar, 2007.

Margaret Gillet. "The IAIN in Indonesian Higher Education." Muslim Education Quarterly 8, no. 1 (1990).

Marwan Salahuddin. "Model Pengembangan Pendidikan Tinggi Islam di Indonesia." Ulumuna: Jurnal Studi Keislaman 18, no. 1 (8 November 2017): 121-38. https://doi.org/10.20414/ujis. v18i1.155.

Michael Laffan. "An Indonesian Community in Cairo: Countinuity and Change in a Cosmopolitan Islamic Milieu." Southeast Asia Program Publication Cornel University 77 (2004). http://www. jstor.org/stable/3351417.

Michel Foucault. The Archeology of Knowledge. London: Tavistock, 1972.

Muhammad Amin Abdullah. "Islamic Studies in Higher Education in Indonesia: Challenges, Impact and Prospects for the World 
Community." Al-Jami'ah: Journal of Islamic Studies 55, no. 2 (2017): 391-426. https://doi.org/10.14421/ajis.2017.552.391- 426.

Muhammad Wahyuni Nafis. Cak Nur sang Guru Bangsa; Biografi Pemikiran Prof. Dr. Nurcholish Madjid. Jakarta: Kompas, 2014.

Mukti Ali. Beberapa Persoalan Agama Dewasa Ini. Jakarta: Rajawali, 1987.

------Memahami Beberapa Aspek Ajaran Islam, 1991.

-------."Penelitian dan Pengembangan Ilmu Pengetahuan Agama Islam." In Pengantar ke Arah Metode Penelitian dan Pengembangan Ilmu Pengetahuan Agama Islam, diedit oleh M Masyhur Amin. Yogyakarta: P3M IAIN Sunan Kalijaga, 1992.

-------."The Muhammadiyah Movement: A Bibliographical Introduction." Tesis, Mc Gill, 1957.

Musahadi. "Islam sebagai Sasaran Studi: Indentifikasi Awal terhadap Problem, Pola, dan Pendekatan Studi Islam di Indonesia." Proceeding ACIS V, Jakarta: Direktorat Pendidikan Tinggi Islam, 2005.

Noorhaidi Hasan. "Meretas Involusi Kajian Hukum Islam di Indonesia: Pengalaman Fakultas Syariah dan Hukum UIN Sunan Kalijaga Yogyakarta." . 46, no. 2 (1 Juli 2012). https:// doi.org/10.14421/asy-syir'ah.2012.\%x.

Nurcholis Madjid. "Ibn Taymiya on Kalam and Falsafah: A Problem of Reason and Revelation in Islam." Dissertation, Universty of Chicago, 1984.

P. Burke. A Social History of Knowledge: From Gutenberg to Diderot. Cambridge: Cambridge University Press, 2000.

R. Eyerman, dan A. Jamison. Social Movement: A Cognitive Approach. Pensylvania: The Pensylvania State University Press, 1991.

Richard Martin. "Harun Nasution and Modern Mu'tazilism." In Defenders of Reason in Islam. Oxford: Oneworld, 1997.

R.T. MCVey. Faith as The Outsider: Islam in Indonesia politic's in Islam in The Political Process, ed. J. P. Piscatori. Cambridge: Cambridge University Press, 1989.

S. Mills. Discourse. London: Routledge, 1999. 
Sudirman Tebba. Orientasi Mahasiswa dan Kajian Islam IAIN," dalam Islam Orde Baru. Yogyakarta: Tiara Wacana, 1993.

Syamsun Ni'am,. "Reformulasi Paradigma Kajian Keislaman di Perguruan Tinggi Agama Islam", dalam Proceeding ACIS IX." Jakarta: Direktorat Pendidikan Tinggi Islam, 2009.

Syamsunniam. "Perguruan Tinggi Agama Islam (PTAI) di Tengah Perubahan: Memetakan Problem, Tantangan, dan Prospek PTAI di Era Kapitalisme Global." Annual Conference on Islamic Studies in Indonesia (ACIS) ke-7, Pekanbaru Riau, 21 November 2007.

Waryani Fajar Rianto. Studi Islam Indonesia (1950-2014): Rekonstruksi Sejarah Perkembangan Program Studi Islam Integratif di Program Pascasarjana Perguruan Tinggi Agama Islam. Yogyakarta: Kurnia Alam Semesta, 2014.

Waryani Fajar Riyanto. “Mazhab Sunan Kalijaga (Refleksi Setengah Abad Genealogi Epistimologi Studi Hukum Islam Integratif di Fakultas Syariah UIN Sunan Kalijaga: 1963-2013." Asy-Syir'ah: Jurnal Ilmu Syariah dan Hukum, 47, no. 2 (2013).

------.Studi Islam Indonesia 1950-2014: Rekonstruksi Sejarah Perkembangan Studi Islam Integratif di Program Pascasarjanaa Perguruan Tinggi Agama Islam (PTAI). Depok: Kurnia Salam Semesta, 2014.

Yudi Latif. Genealogi Intelegensi: Pengetahuan dan Kekuasaan Intelkegensia Muslim Indonesia Abad XX. Jakarta: Kencana Prenadamedia Group, 2012. 